\title{
Correlation between insemination dose and bovine sperm traits on the in vitro embryo production outcomes*
}

\section{Correlação da dose inseminante e características do sêmen bovino no sucesso da produção in vitro de embriões}

\author{
Bárbara Souza Fantin, ${ }^{* *}$ Antônio Santana Santos Filho, ${ }^{* * *}$ Wasim Al Shebli, ${ }^{* * *}$ Júlio César Vieira, ${ }^{* * *}$ \\ Cláudio Coutinho Bartolomeu, ${ }^{* * * *}$ André Mariano Batista, ${ }^{* * *}$ Maria Madalena Pessoa Guerra, ${ }^{* * * *}$ Guilherme Arruda Cezar, ${ }^{* * * *}$ \\ Joana Amélia Senna Costa, ${ }^{* * *}$ Audrey Bagon, ${ }^{* *}$ Carlos André Barbosa Oliveira Filho, ${ }^{* *}$ Pábola Santos Nascimento****
}

\begin{abstract}
In the present study we aimed to test the best insemination dose for in vitro embryo production (IVEP) and to correlate sperm traits in bovine. In vitro matured oocytes were inseminated with three different sperm concentrations of the same bull: $\mathrm{G} 1$ (1*106), G2 $\left(2 * 10^{6}\right)$ and $\mathrm{G} 3\left(4^{*} 10^{6}\right)$ sperm/mL. At $18 \mathrm{~h}$ post-insemination (hpi), presumptive zygotes [G1 $(n=114), \mathrm{G} 2(\mathrm{n}=139)$ and G3 $(\mathrm{n}=136)$ ] were stained to evaluate the pronuclei numbers, or continued to in vitro culture [G1 ( $n=102), G 2(n=111)$ and $G 3(n=106)]$. Sperm kinetics were analyzed using Computer-Assisted Semen Analysis (CASA). Sperm plasma membrane, acrosome integrity and mitochondrial activity were analyzed using fluorescent probes. In vitro fertilization (IVF) and IVEP data were compared using chisquare $(P<0.05)$ and correlated with CASA and fluorescence data using Person Correlation $(P<0.05)$. The IVF efficiency, cleavage and total blastocyst rates did not show any significant difference $(P>0.05)$ among the groups. In $G 3$, the polyspermy rate was the highest $(7.4 \%$; $P<0.05)$ without difference $(P>0.05)$ between $\mathrm{G} 1(0 \%)$ and $\mathrm{G} 2(0 \%)$. In $\mathrm{G} 1$, the early blastocyst rate was the highest (7.8\%; $P<0.05)$, without significant difference $(P>0.05)$ between $G 2(1.8 \%)$ and $G 3(0.9 \%)$. The IVF efficiency and total blastocyst rates were positively correlated with curvilinear velocity $(\mathrm{VCL})(r \simeq+1 ; P<0.05)$. We concluded that the reduction of insemination dose may negatively affect embryo development and VCL may be used as a parameter to improve the IVEP outcomes.
\end{abstract}

Keywords: Blastocysts, CASA, Mitochondrial Activity, Polyspermy.

\section{Resumo}

O objetivo deste estudo foi testar a melhor dose inseminante para a produção de embriões in vitro (IVEP) e sua correlação com as características espermáticas na espécie bovina. Oócitos maturados in vitro foram inseminados com três concentrações diferentes de espermatozoides de único touro: G1 $\left(1^{*} 10^{6}\right)$, G2 $\left(2^{*} 10^{6}\right)$ e G3 $\left(4^{*} 10^{6}\right)$ espermatozoides/mL. Às 18 h pós-inseminação (hpi), os presumíveis zigotos [G1 (114), G2 (139) e G3 (136)] foram corados para avaliar o número de pronúcleos, ou continuaram para o cultivo in vitro [G1 (102), G2 (111) e G3 (106)]. Os parâmetros da cinética espermática foram analisados usando o ComputerAssisted Semen Analysis (CASA). A integridade de membrana plasmática espermática, acrossomal e a atividade mitocondrial foram analisadas usando sondas fluorescentes. Os dados da fertilização in vitro (FIV) e IVEP foram comparadas com qui-quadrado $(P=0,05)$ e correlacionados com dados de CASA e Fluorescência usando Correlação de Pearson $(r= \pm 1 ; P<0,05)$. A eficiência da FIV, taxas de clivagem e blastocisto total não mostraram diferença significativa $(P>0,05)$ entre os grupos. Em G3, a taxa de polispermia foi a maior $(7,4 \%$; $P<0,05)$, sem diferença $(P>0,05)$ entre $G 1(0 \%)$ e $G 2(0 \%)$. Em G1, a taxa de blastocisto inicial foi a maior (7,8\%; $P<0,05)$, sem apresentar diferença significativa $(P>0,05)$ com $G 2(1,8 \%)$ e G3 $(0,9 \%)$. A eficiência de FIV e a taxa de blastocisto total foram positivamente correlacionadas com velocidade curvilinear $(\mathrm{VCL})(\mathrm{P}<0,05)$. Concluímos que a dose inseminante reduzida pode negativamente afetar o desenvolvimento embrionário e VCL pode ser usada como parâmetro para melhorar os resultados da PEIV.

Palavras-Chaves: Blastocisto, CASA, Atividade mitocondrial, Polispermia.

\footnotetext{
*Recebido em 1 de agosto de 2019 e aceito em 29 de abril de 2020.

**Faculdades Integradas Aparício Carvalho (FIMCA); Departamento Medicina Veterinária Brasil; Porto Velho; Rondonia; Brazil.

***Instituto agronômico de Pernambuco (IPA); Estação Experimental em Arcoverde; Laboratório de Melhoramento Genético e Reprodução Animal; Arcoverde; Pernambuco; Brazil.

****Universidade Federal Rural de Pernambuco (UFRPE); Departamento de Medicina Veterinária, Recife; Pernambuco; Brazil. Autor para correspondência: Wasim Al Shebli - wasimalshible81@gmail.com.
} 


\section{Introduction}

In vitro production (IVEP) of bovine embryos has allowed the use of waste biological resource from valuable females to increase their offspring in breeding programs, particularly in Brazil (Viana et al., 2010; Lonergan et al., 2016). Sperm samples that are used in fertilization strongly influence the IVEP outcomes and the bull effect has been generally related as a cause of variation of developmental rates. Attempts to select sperm samples with improved in vitro performance that are based on sperm features would be an interesting tool to improve embryo production yields (Siqueira et al., 2018). Changing the amount of sperm added to the bovine in vitro fertilization (IVF) system impacts the fertilization efficiency (Parrish, 2013). Semen analyses have been used for more than half a century so far to estimate the fertilizing potential of semen sample (Graham and Mocé, 2004). In our experiments we use cryopreserved semen of $5 / 8$ Girolando bulls, a breed that was developed in Agronomic Institute of Pernambuco (IPA) as results of crossbreeding of Gir (Bos taurus indicus) and Frisian Holstein (Bos taurus taurus) (5 to 8 respectively), which shows high resistance to heat stress, mastitis, laminitis, and shows high fertility after artificial insemination (Nascimento et al., 2015). Recently, increasing attention has been paid to the objective evaluation and characterization of sperm movement rather than simply determining of the total proportion of motile spermatozoa. The aim of computer-assisted semen analysis (CASA) is to provide objective values for sperm motility more rapidly and accurately than by traditional methods (visual observation) (Nagy et al., 2015). We hypothesized that sperm traits may be correlated with IVEP outcomes and/or correlated with the activity of mitochondria. In the present study we aimed to find the best sperm concentration for obtaining the best IVEP outcomes after in vitro fertilization (IVF) with sperm from a 5/8 Girolando bull, as well as to find correlations between post-thawing sperm motion parameters, mitochondrial activity, semen plasma membrane and acrosome integrities with IVEP outcomes.

\section{Material and Methods}

The chemical materials were purchased from Gene Up biotechnology company (Presidente Prudente-SP-Brazil), unless otherwise stated. The cryopreserved semen of a $5 / 8$ Girolando bull was prepared in the company of SEMBRA (Barretos-SP$\mathrm{BR}$ ), in straws of $0.5 \mathrm{~mL}$; the experiments were conducted from 29/04 to 29/06/2019 in the Laboratory of Animal Reproduction and Genetic Enhancement in the experimental station of the Agronomic institute of Pernambuco (IPA), in the city of ArcoverdePE-BR (latitude $08^{\circ} 25^{\prime} 08^{\prime \prime}$ south, longitude $37^{\circ} 03^{\prime} 14^{\prime \prime}$ west, 663 meter altitude), semi-arid area; CASA analysis and florescence assays were conducted in AndroLab Rural Federal University of Pernambuco (UFRPE), Recife-PE-BR. To conduct In vitro embryo production (IVEP) process bovine ovaries were collected from a local slaughterhouse in the city of Arcoverde the Cumulusoocyte complex (COCs) were aspirated from antral follicles of 3-5 $\mathrm{mm}$ in diameter with $10 \mathrm{~mL}$ disposable syringe connected with $18 \mathrm{G}$ needle, the follicular liquids that contained COCs were deposited in a tube of $15 \mathrm{~mL}$ that contained $5 \mathrm{~mL}$ of buffering phosphate solution (BPS) in a warm bath $\left(37^{\circ} \mathrm{C}\right)$ then were selected under a stereomicroscope; only the 1st degree COCs were selected according to the number of the layers of cumulus cells ( $>3$ layers) and homogeneity and color of cytoplasm. After the selection, the COCs were washed three times in droplets of washing medium [Tissue culture medium (TCM-199), HEPES, $0,2 \mathrm{mM}$ Sodium Pyruvate, $10 \%$ fetal bovine serum (FBS)] (100 $\mu \mathrm{L})$, then the fourth wash was done in droplet of $(100 \mu \mathrm{L})$ IVM medium [TCM-199, 0.2 mM Sodium Pyruvate, 10\% FBS , 0.1 $\mathrm{mM}$ Cysteamine, $10 \mathrm{ng} / \mathrm{mL}$ epidermal growth factor (EGF), 20 $\mu \mathrm{g} / \mathrm{mL} \mathrm{FSH} / \mathrm{LH}, 1 \mu \mathrm{g} / \mathrm{mL}$ estradiol benzoate (E2)]. Each 15-20 COCs were matured in $(100 \mu \mathrm{L})$ of IVM medium under mineral oil for 24 hours at $38.5^{\circ} \mathrm{C}$, in an atmosphere with saturated humidity and $5 \% \mathrm{CO}_{2}$.

A $0.5 \mathrm{~mL}$ straw of cryopreserved semen was thawed in a warm path $\left(36.5^{\circ} \mathrm{C}\right)$ for 30 seconds and selected in a discontinuous percoll gradient $(45 \%)$. The number of spermatozoa were counted using Neubauer chamber then each group of in vitro matured COCs that were washed three times within IVF-TALP medium [Tyrode's solution with albumin, lactate and pyruvate (TALP), supplemented with $50 \mathrm{mg} / \mathrm{mL}$ heparin] placed in $30 \mu \mathrm{L}$ of IVF-TALP covered with mineral oil, inseminated with three different concentrations $1^{*} 10^{6}, 2^{*} 10^{6}$ or $4^{*} 10^{6}$ sperm $/ \mathrm{mL}$ and incubated for $18 \mathrm{hrs}$ in the same condition used for IVM. 18hpi PZs of each group were denuded by pipetting in three drops of $100 \mu \mathrm{L}$ of saline buffering solution with $5 \%$ BFS, fixed with $0.5 \%$ TRITON X-100 (v/v), and $0.1 \%$ sodium citrate $(\mathrm{w} / \mathrm{v})$, then were stained with Hoechst 33342; finally, the number of pronuclei was verified under inverted fluorescence microscope using (emission wavelength, $512 \mathrm{~nm}$ ). 18hpi the PZs were washed three times in Synthetic Oviductal Fluid (SOF) [ $\mathrm{NaCl} 107.7 \mathrm{mM}, \mathrm{KCl} 7.15 \mathrm{mM}$, $\mathrm{KH}_{2} \mathrm{PO}_{4} 1.19 \mathrm{mM}, \mathrm{CaCl}_{2} 1.71 \mathrm{mM}, \mathrm{MgCl}_{2} 0.49 \mathrm{mM}, \mathrm{NaHCO}_{3}$ $25.07 \mathrm{mM}$, Sodium lactate $3.30 \mathrm{mM}$, Sodium pyruvate $0.3 \mathrm{mM}$, Sodium pyruvate $0.3 \mathrm{mg} / \mathrm{mL}$, and Bovine serum albumin (BSA) $3.0 \mu \mathrm{g} / \mathrm{mL}$ ] (Takahashi and First., 1992) supplemented with $5 \%$ FBS $(100 \mu \mathrm{L})$, then each group was incubated in $100 \mu \mathrm{L}$ of the same medium until $168 \mathrm{hpi}$. The semen straws were thawed in a warm path at $37 \mathrm{C}^{\circ}$ for 30 seconds, aliquots of $5 \mu \mathrm{L}$ (Three aliquots/treatment) was placed on glass slides and covered with coverslips to for photographing using video camera (Basler Vision Technologie A312FC). A minimum of 2000 sperm in 5 inconsecutive fields selected randomly were analyzed. The parameters that were analyzed using Sperm Class Analyzer SCATM software v. 5.1 (Microptics, S.L., Barcelona, Spain) were: progressive motility (PM), linearity (LIN), straightness (STR) and wobble (WOB), that were expressed as percentage, curvilinear velocity (VCL), straight line velocity (VSL), and average path velocity (VAP), were expressed in $\mu \mathrm{m} / \mathrm{s}$; amplitude of lateral head (ALH) was expressed in $\mu \mathrm{m}$; beat cross frequently (BCF) was expressed in hertz. The sperm motion parameters were realized thrice. Also we compared VAP and VSL to have verified the regularity of sperm motion path according to Lu et al. (2013).

The fluorescent probes of Carbocyanine cationic lipophilic (JC1), fluorescein Pisum stavium agglutinin, and Propidium lodide (PI) (all probes were purchased from Molecular Probes, Life Technologies, EUA) were used for evaluating the mitochondrial activity, and acrosome and sperm plasma membrane integrities respectively. $5 \mu \mathrm{L}$ of $\mathrm{JC} 1$ and $\mathrm{PI}$ were added to $20 \mu \mathrm{L}$ of semen separately in two microtubes, and incubated at room temperature for $5 \mathrm{~min}$ and then the samples were analyzed under fluorescence microscope (Carl Zeiss, Göttingen, Germany using BP 450-490 $\mathrm{nm}$ excitation and LP $515 \mathrm{~nm}$ emission filters). The sperm cells that had functional and nonfunctional mitochondria were colored with orange and green respectively (Figure 1.1). The red colored cells indicated the dead sperm (Figure 1.2). For evaluating the acrosome integrity, semen smears were stained with $20 \mu \mathrm{L}$ of 
FITC-PSA and incubated for $1 \mathrm{~h}$-; after then the acrosomes were evaluated according to the coloration, the yellowish green and florescent green acrosomes presented intact acrosome and damaged acrosomes respectively (Figure 1.3).

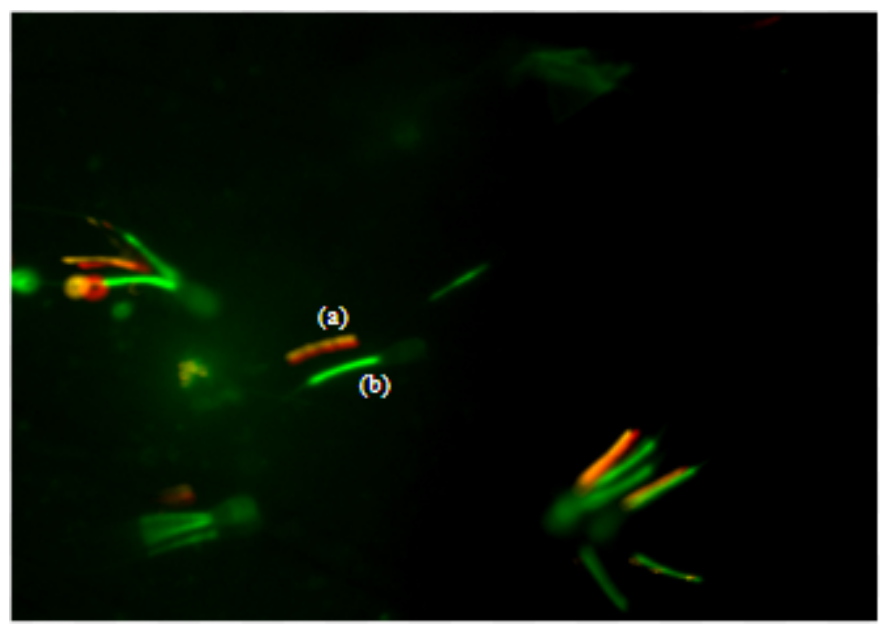

Figure 1.1: Mitochondrial activity (fluorescence microscope Carl Zeiss, Göttingen, *400 magnification), (a) Sperm with Active mitochondria; (b) Sperm with inactive mitochondria.

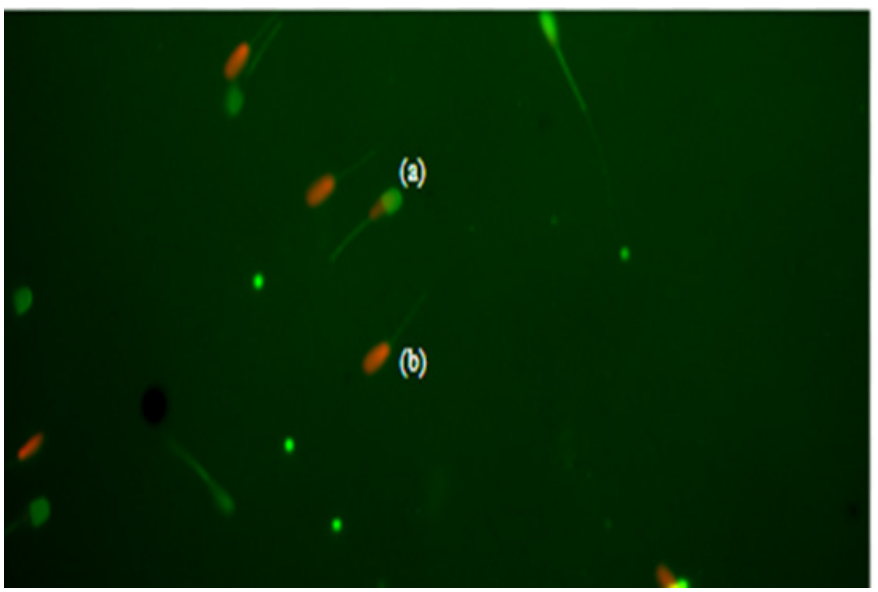

Figure 1.2: Sperm plasma membrane integrity (fluorescence microscope Carl Zeiss, Göttingen, *400 magnification) (a) Intact sperm plasma membrane; (b) Damaged sperm plasma membrane.

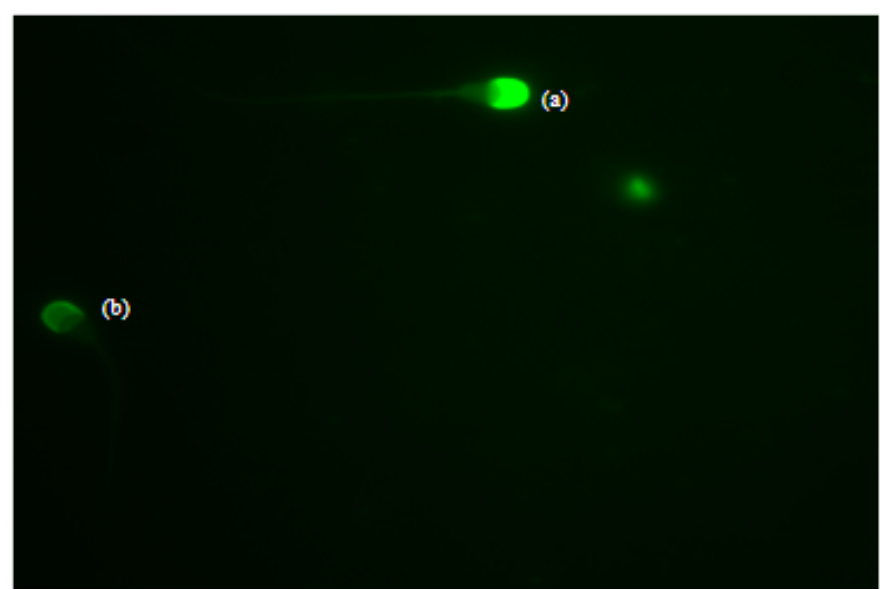

Figure 1.3: Acrosome Integrity (fluorescence microscope Carl Zeiss, Göttingen, *400 magnification) (a) Sperm with intact acrosome; (b) Sperm with damaged acrosome.
The experimental groups were divided after in vitro maturation (IVM) according to the insemination dose (Sperm concentration) into G1 $\left(1^{*} 10^{6}\right), \mathrm{G} 2\left(2^{*} 10^{6}\right)$ and G3 $\left(4^{*} 10^{6}\right) \mathrm{sperm} / \mathrm{mL}$. The fertilization were classified according to pronuclei number in ZPs to IVF efficiency (Pronuclei=2), Polyspermy (Pronuclei>2) or without fertilization (Pronuclei=0), other groups of $\mathrm{PZs}$ were cultured in vitro then 48 and 168 hpi the cleavage and the blastocyst rates were observed and the blastocysts were classified morphologically to early blastocyst, blastocyst, expanded blastocyst, and hatched blastocyst) (Figure 2).

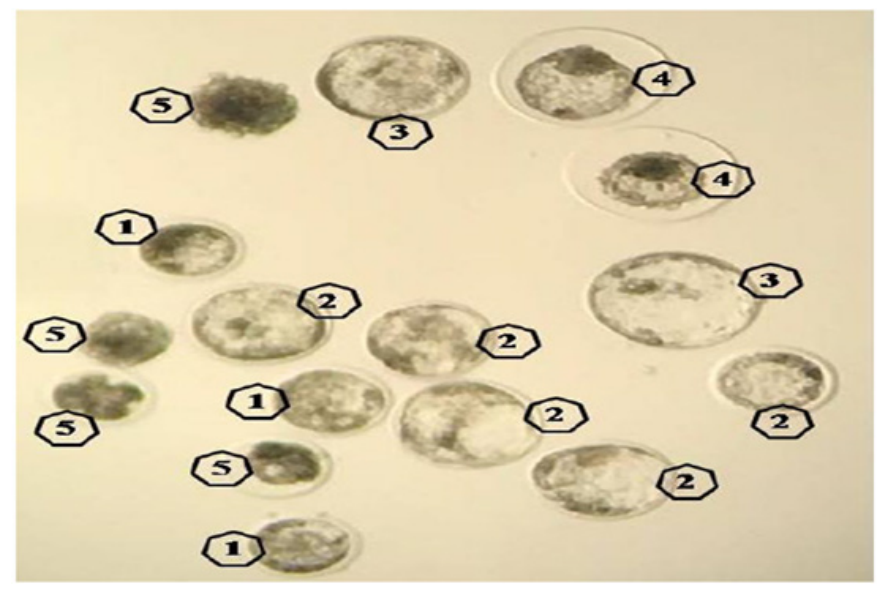

Figure 2: Classification of bovine embryo development at $168 \mathrm{hpi}$ (Stereomicroscope Nikon SMZ745T magnification *1, SAMSUNG Camera PL20, *4 zoom). early blastocyst (1), blastocyst (2), expanded blastocyst (3), hatching blastocyst (4), degenerated blastocyst (5).

Finally the post-thawed semen samples were subjected to CASA, and fluorescent staining.

\section{Statistical Analyses}

The fertilization, polyspermy, cleavage, classification of embryonic development and total blastocyst rates were analyzed using the method of logic regression, and compared with chiSquare test at the significant $P$ value $<0.05$; the data of CASA and fluorescence were correlated with the IVF and IVEP data using the test of Pearson Correlation ( $r=1$ : high positive correlation, $r=-1$ high negative correlation) at the significant $P$ value $<0.05$ the statistical analyses were conducted using SAS software (SAS UNIVERSITY 2018-USA). IVP processes were repeated for 6 times.

\section{Results and Discussion}

There was no significant difference among the groups $(P>0.05)$ in penetration G1 (62.3\%), G2 $(64.0 \%)$ and G3 $(68.4 \%)$ or IVF efficiency rates G1 (62.3\%), G2 (64.0\%) and G3 (61.0\%) polyspermy rate was the highest in $\mathrm{G} 3(\mathrm{P}<0.05)$ without significant difference between other groups ( $P>0.05) \mathrm{G} 1(0 \%)$, G2 (0\%) and G3 (7.4\%) (Table 1). 
Table 1: Fertilization and polyspermy rates, in presumptive zygotes (18 hpi), after in vitro insemination with three different doses of one bull sperm, G1 $\left(1^{*} 10^{6}\right)$, G2 $\left(2 * 10^{6}\right)$ and G3 $\left(4^{*} 10^{6}\right)$ sperm $/ \mathrm{mL}$

\begin{tabular}{lcccc}
\hline *Group & Total & Penetration & IVF efficiency & Polyspermy \\
& $\mathrm{N}$ & $\mathrm{N}(\%)$ & $\mathrm{N}(\%)$ & $\mathrm{N}(\%)$ \\
$\mathrm{G} 1$ & 114 & $71(62.3)$ & $71(62.3)$ & $0(0)^{\mathrm{a}}$ \\
$\mathrm{G} 2$ & 139 & $89(64.0)$ & $89(64.0)$ & $0(0)^{\mathrm{a}}$ \\
$\mathrm{G} 3$ & 136 & $93(68.4)$ & $83(61.0)$ & $10(7.4)^{\mathrm{b}}$ \\
\hline
\end{tabular}

* $N$ : number; $a, b$ the different letters indicate significant difference $(P<0.05)$.

There was no significant difference among the groups $(P>0.05)$ in cleavage G1 (54.9\%), G2 (51.4\%) and G3 (55.7\%) or total blastocyst G1 (16.7\%), G2 (10.8\%) and G3 (10.4\%) rates among the groups; the early blastocyst rate was the highest in $\mathrm{G} 1(7.8 \%)$ $(P<0.05)$ without significant difference between other groups (P>0.05) G2 (1.8\%) and G3 (0.9\%) (Table 2).

Table 2: In vitro embryo development outcomes, cleavage (48 hpi) and blastocyst (168 hpi) and blastocyst classification, after in vitro insemination with three different doses of one bull sperm, G1 $\left(1^{*} 10^{6}\right)$, G2 $\left(2^{*} 10^{6}\right)$ and G3 $\left(4^{*} 10^{6}\right)$ sperm/mL

\begin{tabular}{lccccccc}
\hline${ }^{*}$ Group & Total & Cleavage & $\begin{array}{c}\text { Early } \\
\text { blastocyst }\end{array}$ & Blastocyst & $\begin{array}{c}\text { Expanded } \\
\text { blastocys }\end{array}$ & $\begin{array}{c}\text { Hatched } \\
\text { blastocyst }\end{array}$ & $\begin{array}{c}\text { Total } \\
\text { blastocyst }\end{array}$ \\
\hline & $\mathrm{N}$ & $\mathrm{N}(\%)$ & $\mathrm{N}(\%)$ & $\mathrm{N}(\%)$ & $\mathrm{N}(\%)$ & $\mathrm{N}(\%)$ & $\mathrm{N}(\%)$ \\
$\mathrm{G} 1$ & 102 & $56(54.9)$ & $8(7.8)^{\mathrm{a}}$ & $4(3.9)$ & $3(2.9)$ & $2(2.0)$ & $17(16.7)$ \\
$\mathrm{G} 2$ & 111 & $57(51.4)$ & $2(1.8)^{\mathrm{b}}$ & $3(2.7)$ & $2(1.8)$ & $5(4.5)$ & $12(10.8)$ \\
$\mathrm{G} 3$ & 106 & $59(55.7)$ & $1(0.9)^{\mathrm{b}}$ & $6(5.7)$ & $1(0.9)$ & $3(2.8)$ & $11(10.4)$ \\
\hline
\end{tabular}

${ }^{*} \mathrm{~N}$ : Number; $\mathrm{a}, \mathrm{b}$ the different letters indicate significant difference $(P>0.05)$.

The fertilization rate was positively correlated with the medium progress $A L H(r \simeq+1, P<0.05)$; IVF efficiency rate was positively correlated with the Total VCL $(r \simeq+1, P<0.05)$, the polyspermy rate was positively correlated with the $\mathrm{PM}(\mathrm{r} \simeq+1, \mathrm{P}<0.05)$ (Table 3$)$.

Table 3: Correlation among sperm motion parameter obtained with CASA and fertilization and polyspermy rates in zygotes

\begin{tabular}{lccc}
\hline 1Parameter & $\begin{array}{c}\text { Penetration } \\
(\mathrm{r} / \mathrm{p})\end{array}$ & $\begin{array}{c}\text { IVF efficiency } \\
(\mathrm{r} / \mathrm{p})\end{array}$ & $\begin{array}{c}\text { Polyspermy } \\
(\mathrm{r} / \mathrm{p})\end{array}$ \\
\hline PM $(\%)$ & 0.63332 & 0.17988 & 0.99996 \\
& 0.5634 & 0.8849 & $0.0059^{*}$ \\
Total VCL $(\mu \mathrm{m} / \mathrm{s})$ & 0.89058 & 0.99946 & 0.22108 \\
& 0.3006 & $0.0209^{*}$ & 0.8581 \\
Slow WOB $(\%)$ & 0.66636 & 0.22246 & 0.99941 \\
& 0.5357 & 0.8572 & $0.0218^{*}$ \\
Medium ALH $(\mu \mathrm{m})$ & 0.99838 & 0.84624 & 0.68313 \\
& $0.0362^{*}$ & 0.3577 & 0.5212 \\
\hline
\end{tabular}

*Significant correlation; ${ }^{1} \mathrm{PM}$ : progressive motility, WOB: wobble, VCL: curvilinear velocity.
Total VCL and rapid ALH were positively correlated with total blastocyst rate $(r \simeq+1, P<0.05)$, rapid $V S L$ was positively correlated with cleavage rate $(r \simeq+1, P<0.05), P M$ and fast $P M$ were positively correlated with non-cleavage rate $(r \simeq+1, P<0.05)$ (Table 4).

In the present study we found that adjusting of in vitro insemination dose did not improve IVF or IVEP outcomes, only at the insemination dose up to $4^{*} 10^{6} \mathrm{sperm} / \mathrm{mL}$ only at the insemination dose up to $4^{*} 10^{6} \mathrm{sperm} / \mathrm{mL}$ number of polyspermic zygotes was increased $(P<0.05)$, but did not affect the IVEP outcomes; the embryo development at 168 hpi was improved in the $\mathrm{G} 2$ and $\mathrm{G} 3$ due to low early blastocyst rate in the $\mathrm{G} 1$. In the work of Palma and Sinowatz (2004), correlation coefficients of six bulls showed no significant male effect on the cleavage but there was on the blastocyst development, in the present study the insemination dose showed an effect on embryo development, but not on total blastocysts. Parrish (2013) found that changing the amount of sperm that are added to the bovine IVF system impacts the fertilization which is associated with polyspermy rates also the same author confirmed that when fertilization rates exceed $80 \%$, polyspermy begins to increase, thus impacting eventual development rates; in the present study there was no significant difference in penetration rate among the groups $(P>0.05)$ and the polyspermy had no impact on the IVEP outcomes. Ward et al. (2002), found that the best results of IVEP were obtained with the concentrations of $0.25^{\star} 10^{6}$ and $0.5^{\star} 10^{6}$ sperm $/ \mathrm{mL}$, comparing with the results of insemination with concentrations that were within the range $0.01 * 10^{6}$ to $1 * 10^{6}$ sperm $/ \mathrm{mL}$, which was contrary to our results. One year later Ward et al. (2003), found that the reduction in in vitro sperm concentration did not increase the probability of optimizing the fertility or cleavage rate among the bulls of different artificial insemination fertility. Alomar et al. (2008), found that the formation of pronuclei is related to each bull, here we compared the penetration rate and IVF efficiency among three different concentrations of one bull which did not show any significant different; $(P>0.05)$. Additionally, Alomar et al. (2008), related the in vitro embryo development to the kinetics of pronuclear formation, which we did not observe in the present study. The main findings of Ward et al. (2001) were that the used sire in IVF can have a profound effect on the proportion of oocytes developing to the blastocyst stage, in the present study we found that the developmental stage was affected by the insemination dose. Thus, we found that reduction of the insemination dose of semen may negatively affect the embryo development.

Three values of sperm motion velocity are: Curvilinear velocity (VCL, $\mu \mathrm{m} / \mathrm{s})$; which refers to the time-averaged velocity of a sperm head along its actual curvilinear path, and it is always the highest among the values of VCL, VSL and VAP, Straight-line velocity (VSL, $\mu \mathrm{m} / \mathrm{s})$; which refers to the time-averaged velocity of a sperm head along the straight line between its first detected position and its last, which reflects the net space of a sperm 
Table 4: Correlation between sperm motion parameters obtained with Computer-Assisted Semen Analysis (CASA) and IVEP outcomes

\begin{tabular}{lccccc}
\hline 1Parameter & Cleavage & Non-cleavage & Expanded Blastocys & Hatched Blastocyst & Total Blastocyst \\
& $(\mathrm{r} / \mathrm{p})$ & $(\mathrm{r} / \mathrm{p})$ & $(\mathrm{r} / \mathrm{p})$ & $(\mathrm{r} / \mathrm{p})$ & 0.97526 \\
\hline Total VCL $(\mu \mathrm{m} / \mathrm{s})$ & 0.84916 & 0.22108 & 0.99418 & 0.1419 & 0.99981 \\
& 0.3542 & 0.8581 & 0.0687 & 0.95416 & $0.0125^{*}$ \\
Rapid VSL $(\mu \mathrm{m} / \mathrm{s})$ & 0.99956 & -0.29928 & 0.91354 & 0.1935 & 0.85435 \\
& $0.0188^{*}$ & 0.8065 & 0.2667 & 0.95610 & 0.3479 \\
Rapid ALH $(\mu \mathrm{m})$ & 0.80752 & 0.29303 & 0.98341 & 0.1893 & $0.0349^{*}$ \\
& 0.4016 & 0.8107 & 0.1161 & -0.00926 & 0.23119 \\
PM $(\%)$ & -0.33606 & 0.99996 & 0.10550 & 0.9941 & 0.8515 \\
& 0.7818 & $0.0059^{*}$ & 0.9327 & -0.03683 & 0.20428 \\
Fast PM $(\%)$ & -0.36190 & 0.99932 & 0.07805 & 0.9765 & 0.8690 \\
\hline
\end{tabular}

* Significant correlation, ${ }^{1} \mathrm{PM}$ : progressive motility, VCL: curvilinear velocity, VSL: straight line velocity, ALH: amplitude of lateral head.

Table 5: Correlation between mitochondrial activity after staining with $\mathrm{JC} 1$ and sperm motion parameters obtained with CASA

\begin{tabular}{lcc}
\hline${ }^{1}$ Parameters & Active Mitochondria & Inactive Mitochondria \\
\hline Total VAP $(\mu \mathrm{m} / \mathrm{s})$ & $(\mathrm{r} / \mathrm{p})$ & $(\mathrm{r} / \mathrm{p})$ \\
& 0.84750 & -0.99722 \\
Slow VAP $(\mu \mathrm{m} / \mathrm{s})$ & 0.3562 & $0.0475^{*}$ \\
& -0.80519 & 1.000 \\
Total STR $(\%)$ & 0.4041 & $0.0004^{*}$ \\
& -0.79794 & 0.99992 \\
\hline
\end{tabular}

* Significant correlation; ${ }^{1}$ STR: straightness, VAP: average path velocity.

forward motility during the observation period and is always the lowest among the values of VCL, VSL and VAP, and Average path velocity (VAP, $\mu \mathrm{m} / \mathrm{s})$; VAP refers to the time-averaged velocity of a sperm head along its average path (Lu et al., 2013). The results of present study agree with Lu et al., 2013, since we found that the VCL was the highest, and VSL was the lowest among the values of VCL, VSL, and VAP; 76.2, 28.5 and 45.9 $\mu \mathrm{m} / \mathrm{s}$ respectively. According to Lu et al. (2013), if a sperm motion trajectory is very regular and linear, VAP is almost identical to VSL, but in the case of irregular sperm motion path, VAP is much higher than VSL. In cryopreserved/thawed semen samples of the present study, we found that truly VAP was much higher than VSL which indicated the irregularity of sperm motion path. However, Nagy et al. (2015) found that the VAP is the most useful semen motility characteristic which has clinical relevance in the prediction of fertility of artificial insemination, in our laboratory we found that the sexed semen samples showed differences among three bulls in curvilinear speed, linear speed and path velocity variables, that simultaneously showed differences in IVEP outcomes (Nascimento et al., 2015).

In the present study the PM and the fast progressive W.H.O were positively correlated with polyspermy rate $(p<0.05)$; Tanghe et al.
(2002), found that the sperm motility is important for successful fertilization after evaluating the sperm motion visually, which we did not find in our work. Three velocity ratios are: Linearity (LIN), which refers to the linearity of a curvilinear path, namely VSL/VCL, STR which refers to the linearity of the average path, namely VSL/VAP, and WOB which refers to the oscillation of the actual path about the average path, and it is expressed as VAP/VCL (Lu et al., 2013). In the present study neither LIN nor STR were correlated with IVEP outcomes, but polyspermy rate was correlated positively with the PM, Fast Progressive Motility (W.H.O) and Slow WOB $(r \simeq+1, P<0.05)$. Two parameters of sperm wobble characteristics are ALH, which is the magnitude of lateral displacement of a sperm head about its average path and BCF which refers to the average rate at which the curvilinear path crosses the average path, which is a useful parameter assessing the changes in wobble way of a sperm flagellum (Lu et al., 2013); in the present study rapid ALH was positively correlated $(r \simeq+1, P>0.05)$ with total blastocyst rate, meanwhile BCF did not correlate with IVEP outcomes. Thus, we may conclude that the ALH may be a predictor of IVEP outcome.

Thomas et al. (1998), found a positive correlation between the mitochondrial activity and motility in fresh bull semen, but not with post-thawing one using $\mathrm{JC} 1$; our results agree with Thomas et al. (1998), in the present study we only analyzed the mitochondrial activity of post-thawing bull semen, we also found that the active mitochondria did not show any correlation with any sperm motion parameter. Siqueira et al. (2018), found after comparing the data of 63 batches of semen, that the low mitochondrial membrane potential and acrosome and sperm plasma membrane showed highest embryo development and blastocyst rates. The results of present study did not show any correlation among the mitochondrial activity acrosome or sperm plasma membrane integrity and IVEP outcomes. Tanghe et al. (2002), found that after sperm thawing, high mitochondrial activity was higher in bulls with high in vitro fertility than in bulls with low in vitro fertility. The same authors found also that the percentage of sperm with high 
mitochondrial activity was moderately correlated with the IVF outcomes but was not a significant criterion for the selection of spermatozoa for IVF. This last observation is partially agrees with our results because there was no correlation between the activity of mitochondrial activity and IVEP outcomes. In our laboratory Nascimento et al. (2015) found that the integrity of acrosome and sperm plasma membrane integrities as well as the mitochondrial activity were consistent with the fertilization potential of semen samples from $5 / 8$ Girolando bulls, which we did not find it in the present study, here it may be hypothesized that this phenomenon is related to the individual sire.

\section{References}

ALOMAR, M.; TASIAUX, H.; REMACLE, S.; GEORGE, F.; PAUL, D.; DONNAYA, I. Kinetics of fertilization and development, and sex ratio of bovine embryos produced using the semen of different bulls. Animal reproduction science, v.107, n.1-2, p.48-61, 2008.

GRAHAM, J.K.; MOCÉ, E. Fertility evaluation of frozen/thawed semen. Theriogenology, v.64, n.3, p.492-504, 2005.

LONERGAN, P.; FAIR, T. Maturation of oocytes in vitro. Annual Review of Animal Biosciences, v.4, p.255-268, 2016.

LU, J.C.; HUANG, Y.F.; LU, N.Q. Computer-aided sperm analysis: past, present and future. Andrologia, v.46, n.4, p.329-338, 2014.

NAGY, A.; POLICHRONOPOULOS, T.; GASPARDY, A.; SOLTLI, L.; CSEH, S. Correlation between bull fertility and sperm cell velocity parameter generated by Computer-Assisted Semen Analysis. Acta Veterinaria Hungarica, v.63, n.3, p.370-381, 2015.

NASCIMENTO, P.S.; CHAVES, M.S.; SANTOS FILHO, A.S.; GUIDO, S.I.; GUERRA, M.M.P.; BARTOLOMEU, C.C. Production of in vitro embryos using sexed sperm of $5 / 8$ Girolando bulls. Ciência Animal Brasileira, v.16, n.3, p.358-368, 2015.

PALMA, G.A.; SINOWATZ, F. Male and Female Effects on the In Vitro Production of Bovine Embryos. Anatomia, histologia, embryologia, v.33, n.5, p.257-262, 2004.

PARRISH, J.J. Bovine In vitro fertilization: In vitro oocyte maturation and sperm capacitation with heparin. Theriogenology, v.81, n.1, p.67-73, 2014

SIQUEIRA, A.F.P; CASTRO L.S.; ASSIS P.M.; BICUDO, L.D.C; MENDES, C.M.; NICHI, M. Sperm traits on in vitro production (IVP) of bovine embryos: Too much of anything is good for nothing. PLoS ONE, v.13, n.7, p. e0200273, 2018.

\section{Conclusion}

The reduction of the insemination dose may negatively affect the embryo development which is important for embryo transfer (ET). The Computer-Assisted Semen Analysis (CASA) can be a promising tool to verify the in vitro fertility of bull sperm before using it in the processes of in vitro embryo production (IVEP) to save time and costs. VCL may predict the IVF efficiency and IVEP outcomes, and the Progressive Motility may predict the polyspermy rate. Sperm plasma membrane and acrosome integrities and mitochondrial activity may not predict IVEP outcomes.

TANGHE, S.; SOOM, A.V.; STERCKX, V.; MAES, D.; KRUIF, A. Assessment of Different Sperm Quality Parameters to Predict in vitro Fertility of Bulls. Reproduction in Domestic Animals, v.37, n.3, p.127-132, 2002.

TAKAHASHI, Y.; FIRST, N.L. In vitro development of bovine onecell embryos: influence of glucose, lactate, pyruvate, amino acids and vitamins. Theriogenology, v. 37, n.5, p.963-978, 1992.

THOMAS, C.A.; GARNER, D.L.; DEJARNETTE, J.M.; MARSHALL, C.E. Effect of cryopreservation on bovine sperm organelle function and viability as determined by flow cytometry. Biology of reproduction, v.58, n.3, p.786-793, 1998.

VIANA, J.K.; SIQUEIRA, L.G.B.; PALHÃO, M.P.; CAMARGO, L.S.A. Use of in vitro fertilization technique in the last decade and its effect on Brazilian embryo industry and animal production. Acta Scientiae Veterinariae, v.38, n.2, p.661-674, 2010.

WARD, F.; ENRIGHT, B.; RIZOS, D.; BOLAND, M.; LONERGAN, $P$. Optimization of in vitro bovine embryo production: effect of duration of maturation, length of gamete co-incubation, sperm concentration and sire. Theriogenology, v.57, n.8, p.2105-2117, 2002.

WARD, F.; RIZOS, D.; POLAND, M.P.; LONERGAN, P. Effect of reducing sperm concentration during IVF on the ability to distinguish between bulls of high and low field fertility: work in progress. Theriogenology, v.59, n.7, p.1575-1584, 2003.

WARD, F.; RIZOS, D.; CORRIDAN, D.; QUINN, K.; BOLAND, M.; LONERGAN, P. Paternal influence on the time of first embryonic cleavage post insemination and the implications for subsequent bovine embryo development in vitro and fertility in vivo. Molecular Reproduction and Development: Incorporating Gamete Research, v.60, n.1, p.47-55, 2001. 